\title{
Changes of antioxidant enzymes in 'Thomson-Navel' orange during induction of resistance to green mold (Penicillium digitatum (Pers.) Sacc.) as provoked by jasmonic acid, epibrassinolide, chitosan and cin- namon essential oil
}

\author{
Behrooz ALIJOO ${ }^{1}$, Vahid ABDOSSI ${ }^{1,2}$, Vahid ZARRINNIA ${ }^{3}$, Sepideh Kalateh JARI ${ }^{1}$, Mohammad \\ CHAMANI $^{4}$
}

Changes of antioxidant enzymes in 'Thomson-Navel' orange during induction of resistance to green mold (Penicillium digitatum (Pers.) Sacc.) as provoked by jasmonic acid, epibrassinolide, chitosan and cinnamon essential oil

Abstract: Pathogenic agents are one of the causes of postharvest citrus fruit loss. Therefore, the aim of this study was to evaluate the effect of post-harvest treatments with jasmonic acid (ja), epibrassinolide (epiBL), chitosan (chi) and cinnamon essential oil (cin) on induction of resistance to the citrus green mold (Penicillium digitatum (Pers.) Sacc.) and reduction of fungal growth by improving the activity of some antioxidant enzymes in 'Thomson-Navel'orange. For this purpose, a factorial experiment was conducted in a completely randomized design. Treatments included positive and negative control, jasmonic acid $\left(5,10,20\right.$ and $\left.40 \mu \mathrm{l}^{-1}\right)$, epibrassinolide $(1,4,7$ and $\left.10 \mu \mathrm{mol} \mathrm{l}^{-1}\right)$, chitosan $\left(2.5,5,7.5\right.$ and $\left.10 \mathrm{~g} \mathrm{l}^{-1}\right)$ and cinnamon essential oil (250, 500, 750 and 1000 ppm). Characteristics such as lesion diameter and activities of antioxidant enzymes including SOD, APX, CAT and POD were evaluated for a period of 96 hours with 24 hour intervals. The results indicated that all treatments significantly decreased the lesion diameter of fruits. Consequently, chitosan treatments (7.5 and $\left.10 \mathrm{~g} \mathrm{l}^{-1}\right)$ and cinnamon essential oil (750 and $1000 \mathrm{ppm}$ ) inhibited the spread of fungal infection better than other treatments, and therefore reduced the growth of green mold. Also, different concentrations of (ja) and (chi) increased the activity of SOD and APX enzymes, while different concentrations of (epiBR) and (cin) stimulated the activity of POD and CAT enzymes. Finally, the present study proposes using natural products as an appropriate alternative to fungicides in order to reduce the citrus green mold rot.

Key words: peroxidase; catalase; superoxide dismutase; ascorbate peroxidase; citrus green mold; inoculation; lesion diameter
Received May 16, 2019; accepted September 30, 2019.

Delo je prispelo 16. maja 2019, sprejeto 30. septembra 2019.

Spremembe $\mathbf{v}$ antioksidacijskih encimih pri pomaranči 'Thomson-Navel' med indukcijo odpornosti na zeleno plesen (Penicillium digitatum (Pers.) Sacc.), vzpodbujene $\mathrm{z}$ jasmonsko kislino, epibrasinolidom, hitozanom in cimetovim eteričnim oljem

Izvleček: Patogeni so agensi, ki povzročajo izgubo pridelka citrusov po obiranju. Namen raziskave je bil ovrednoti učinek tretiranja plodov citrusov po obiranju $\mathrm{z}$ jasmonsko kislino (ja), epibrasinolidom (epiBL), hitozanom (chi) in cimetovim eteričnim oljem (cin) na indukcijo odpornosti proti zeleni plesni citrusov (Penicillium digitatum (Pers.) Sacc.) in zmanjšanje rasti glive $\mathrm{z}$ izboljšanjem aktivnosti nekaterih antioksidacijskih encimov $\mathrm{v}$ 'Thomson-Navel' pomarančah. $\mathrm{V}$ ta namen je bil izveden popolni naključni faktorski poskus. Obravnavanja so obsegala kontrolo in tretiranje pomaranč $\mathrm{z}$ jasmonsko kislino $\left(5,10,20\right.$ in $\left.40 \mu \mathrm{l} \mathrm{l}^{-1}\right)$, epibrasinolidom $\left(1,4,7\right.$ and $\left.10 \mu \mathrm{mol} \mathrm{l}^{-1}\right)$, hitozanom $\left(2,5 ; 5 ; 7,5\right.$ and $\left.10 \mathrm{~g} \mathrm{l}^{-1}\right)$ in cimetnim eteričnim oljem $(250,500,750$ in $1000 \mathrm{ppm})$. Znaki kot so premer lezije s plesnijo in aktivnost antioksidacijskih encimov kot so SOD, APX, CAT in POD so bili ovrednoteni po obdobju 96 ur s 24 urnimi intervali. Rezultati so pokazali, da so vsa obravnavanja značilno zmanjšala premer lezij s plesnijo na plodovih. Obravnavanja s hitozanom (7,5 in $\left.10 \mathrm{~g} \mathrm{l}^{-1}\right)$ in eteričnim oljem cimeta (750 in $1000 \mathrm{ppm}$ ) so bolj zavrla širjenje glive kot ostala in so tako zmanjšala rast zelene plesni. Različne koncentracije jasmonske kisline in hitozana so povečale aktivnosti SOD in APX encimov, medtem, ko so različne koncentracije epibrasinolida in cimetovega eteričnega olja stimulirale aktivnost POD in CAT enzimov. Na osnovi te raziskave lahko priporočamo uporabo naravnih snovi kot primerno alternativo fungicidom pri zmanjševanju gnitja plodov citrusov zaradi zelene plesni.

Ključne besede: peroksidaza; katalaza; superoksid dismutaza; askorbat peroksidaza; zelena plesen citrusov; inokulacija; premer lezij

1 Islamic Azad University, Department of Horticultural Sciences, Science and Research Branch, Tehran, Iran

2 Corresponding author, e-mail: abdossi@srbiau.ac.ir

3 Islamic Azad University, Department of Plant Protection, Science and Research Branch, Tehran, Iran

4 Islamic Azad University, Department of Animal Sciences, Science and Research Branch, Tehran, Iran 


\section{INTRODUCTION}

Citrus is considered as an important fruit in all over the world, and is cultivating in all parts of the world and have a 4,000 years history in China's agricultural system (Ladanyia and Ladaniya, 2010). Iran has the eighth rank in global citrus production with a production of 1,946169 tons in 2016 (FAO, 2019). Postharvest diseases cause significant damage to harvested fruits and vegetables during transporting and storing (Sharma et al., 2009).There are two major factors that make plant products more susceptible to damage: The more water content in the fruit provides the pathogen attack conditions, and after that, wound is generated at the plant's organs during harvest and transportation (Sharma et al., 2009). Following skin damage, many species of pathogenic fungi attack it. More than 20 species of citrus diseases have been reported up to date, during the post-harvest period. Among them, the green and blue molds rot that are produced by $P$. digitatum (Pers.) Sacc. and P. italicum Wehmer fungi, respectively, are the worst due to they can easily result in fruit decay and deterioration. Generally, the rate of fruit rot remains approximately between $10 \%$ and $30 \%$, however it increases up to $50 \%$ in worse conditions and causes widespread economic losses, especially in developing countries (Ladanyia and Ladaniya, 2010). Nowadays, post-harvest citrus diseases are mainly controlled by chemical fungicides such as imazalil, benzimidazole, thiabendazole, prochloraz and pyrmethanil, which long-term and persistent using of them causes resistance to pathogens along with environmental pollution. Since fungicides remain on the surface of citrus fruits and have been reported to be harmful for human health, using alternative methods are expanding as a global trend that are more profitable and efficient, less toxic to the environment and human and also are inexpensive (Jimenez-Reyes et al., 2018). Over the past thirty years, extensive studies have been performed to develop new methods based on the microbial antagonists for biological control of postharvest pathogens (Droby et al., 2009).

Enzymes are key factors in the management of fresh products quality. Each enzyme plays an important role in the plant's physiological process. Previous reports demonstrated that the major enzymes in the plant (Polyphenol Oxidase, Phenylalanine Ammonia Lyase, Catalase and Superoxide Dismutase) are regulating the defense mechanism against fungal pathogens in fruits (Wang et al., 2009).

Methyl jasmonate is considered as an important plant hormone that can modulate plant defense responses, including antioxidant systems (Wasternack and Hause,
2013). This material has an important influence on the content of secondary metabolites in different types of fruit and is also important for the development of natural defense systems against abiotic stresses and post-harvest decay (González et al., 2003). During a study, the preventive action of methyl jasmonate (MeJA) was evaluated alone and in combination with the antagonistic yeast (Cryptococcus laurentii (Kuff.) C.E. Skinner) in suppressing the green mold in citrus fruits. The results showed that at the concentration level $100 \mathrm{~mol} \mathrm{l}^{-1}$ of methyl jasmonate, the incidence of disease and decay diameters decreased compared to the control. Also, the use of methyl jasmonate increased the activity of polyphenol oxidase, peroxidase and catalase compared to the control (Guo et al., 2014).

Brassinoestroides are considered as the sixth group of plants hormones (Luan et al., 2013).It is also proposed that brassinoestroides are natural, non-toxic, and environmental friendly phytohormones, and consequently can be used in agriculture to improve growth, yield and post-harvest quality (Coll et al., 2015). In a study, the effects of brassinosteroids (BRs) on the blue mold caused by Penicillium expansum Link and jujube fruit senescence were investigated. Brassinosteroids at $5 \mu \mathrm{m}$ concentration, effectively inhibited the growth of blue mold and increased the activity of defense-related enzymes such as phenylalanine ammonia lyase, polyphenol oxidase, catalase and superoxide dismutase (Zhu et al., 2010).

Chitosan is a natural compound that has good potential in agriculture for controlling plant diseases. This molecule shows toxicity, and inhibits the growth and development of fungi (Zhang et al., 2011). In addition, chitosan is a polysaccharide and produced by chitin deacetylation and can also be used to form a fully edible semipermeable layer on the outer surface of the fruit to extend its postharvest life and reduce different types of fungus-induced decay during storage process (Bautista-Banos et al., 2006). During a research, the effects of chitosan on green mold and quality characteristics of citrus fruit were investigated. The results of an in vivo study showed that the green mold was significantly reduced by the chitosan treatment. In the same way, the activity of chitinase and glucanase enzymes in coated fruits increased. Evidence has shown that the effect of chitosan coating on green mold of citrus fruits may be attributed to its antifungal properties to the pathogen or to the development of biochemical defense responses in coated fruits (El Guilli et al., 2016).

Herbal essences indicated antimicrobial activity against a variety of pests and plant diseases. Several studies have investigated the potential of herbal essences as antifungal agents, including cinnamon essence (Abdolahi et al., 2010). Cinnamon (Cinnamomum verum J. Presl) is from Lauraceae family, Cinnamomum genus and Cinnamomum verum (C. zeylandicum Blume). It has been 
determined that the essential oil of cinnamon contains 50-80\% cinnamaldehyde and about $2 \%$ eugenol and the essential oil of its leaves is rich in eugenol (70-75\%)(Shan et al., 2007). Antifungal activity of cinnamon, pepper and garlic extracts combined with chitosan as a covering on fungal rot of banana cluster (Colletotrichum musae (Berk. \& M. A. Curtis) Ar., Fusarium spp and Lasiodiplodia theobromae (Pat.) Griffon \& Maubl.) were evaluated under laboratory conditions. The results showed that cinnamon essential oil with a concentration of $5 \mathrm{mg} \mathrm{l}^{-1}$, completely prevented germination of conidia and mycelium growth in all fungi (Win et al., 2007).

The purpose of this study was to evaluate the effects of treatments to control post-harvest disease of citrus green mold on orange fruit during storage process and also to protect the environment from the harmful effects of fungicides. In this study, we investigate the antifungal activity of jasmonic acid, epibrassinolide, chitosan and cinnamon essential oil against citrus green mold.

\section{MATERIALS AND METHODS}

\subsection{PREPARATION OF PLANT MATERIALS}

Thomson-Navel oranges (C. sinensis ${ }^{\circ}$ Thomson Navel') were harvested from a commercial orchard located in Tonekabon, Iran. In a physiological maturation state and after full dyeing in early 2016, were immediately transferred to the Plant Pathology Laboratory of Islamic Azad University, Science and Research branch in Tehran. Then, uniform fruits in terms of size and color and without physical damage were selected for treatment application.

\subsection{PREPARING OF PATHOGEN INOCULUM}

In order to prepare the pathogenic inoculum, the Penicillium digitatum (Per.) Sacc. fungus was isolated from the infected 'Thomson-Navel' oranges and cultured on potato dextrose agar medium (Yao and Tian, 2005).After 2 weeks, spores were removed from the culture medium to prepare spore suspension using sterile distilled water (containing $0.5 \mathrm{ml}$ Tween 80 ). Then, spore suspension of the green mold pathogen was prepared using the Hemocytometer with a concentration of $1 \times 10^{5}$ spore $\mathrm{ml}^{-1}$ (Qin et al., 2003).

\subsection{APPLYING TREATMENTS AND INOCULAT- ING FRUITS WITH PATHOGEN}

For surface sterilization, the fruits were immersed in sodium hypochlorite $0.1 \%$ for 30 seconds and then washed twice with the sterilized distilled water. After drying, fruits were dipped for 3 minutes in pre-prepared solutions of jasmonic acid $(5,10,20$ and $40 \mu \mathrm{l}$ $\left.\mathrm{l}^{-1}\right)$, epibrassinolide $\left(1,4,7\right.$ and $\left.10 \mu \mathrm{mol} \mathrm{l^{-1 }}\right)$, chitosan (2. 5, 5, 7.5 and $\left.10 \mathrm{~g} \mathrm{l}^{-1}\right)$ and cinnamon essential oil $(250,500,750$ and $1000 \mathrm{ppm})$. Control treatments included infected control(healthy fruits inoculated with the pathogen spore and dipped in sterile distilled water containing $0.05 \%$ tween 80 ) and healthy control (healthy fruits dipped in sterile distilled water containing $0.05 \%$ tween 80) (Reddy et al., 1997). After 24 hours of fruit treatment, they were then wounded with a sterilized nail at 2 points ( $4 \mathrm{~mm}$ deep and $3 \mathrm{~mm}$ in diameter) in the equatorial zone and inoculated with $20 \mu \mathrm{l}$ spore suspension of $P$. digitatum. After that, the inoculated fruits were placed in special plastic bags to maintain the relative humidity of about $95 \%$ and stored at $20^{\circ} \mathrm{C}$ for 96 hours. All traits were evaluated over a period of 96 hours (every 24 hours) (Peng et al., 2009). Each treatment was replicated three times, and the experiment was conducted twice.

Chemicals: all compounds for the treatments were purchased from Aldrich Chemicals (Milwaukee) and to extract the essential oil of cinnamon, the dried cinnamon pieces were crushed by milling.

\subsection{EVALUATION OF LESION DIAMETER AND ANTIOXIDANT ENZYMES ACTIVITY MEAS- UREMENTS}

In order to evaluate the lesion diameter of the fruit, from each fruit at specific times (immediately, and 24, 48, 72 and 96 hours after inoculation) two diameters of infection were obtained, and their average was considered as the lesion diameter for that fruit at that specific time. Also, a portion of the healthy mesocarp tissue was removed for enzymatic studies at immediately, 48, 72 and 96 hours after inoculation (enzymatic evaluation was not performed at 24 hours after inoculation due to no infection). Samples were then mixed and frozen immediately in liquid nitrogen, then stored at $-80^{\circ} \mathrm{C}$ (Peng et al., 2009).

\subsubsection{Extraction of enzyme}

The enzyme extract was prepared by homogenizing $1 \mathrm{~g}$ of tissue sample with $3 \mathrm{ml}$ sodium phosphate buffer, at ( $\mathrm{pH}$ 6.7). The homogenate was centrifuged at $18,000 \times \mathrm{g}$ for $15 \mathrm{~min}$ at $4{ }^{\circ} \mathrm{C}$. After complete sedimen- 
tation, the supernatant served as the enzyme source (Mac-Adam et al., 1992).

\subsubsection{Superoxide dismutase activity (SOD)}

To measure the superoxide dismutase enzyme, $1500 \mu \mathrm{l}$ phosphate buffer $50 \mathrm{mmol}, 300 \mu \mathrm{l}$ sodium carbonate $50 \mathrm{mmol}, 300 \mu \mathrm{l}$ methionine $12 \mathrm{mmol}, 300 \mu \mathrm{l}$ nitro blue tetrazolium chloride $75 \mu \mathrm{mol}, 300 \mu \mathrm{l}$ riboflavin $1 \mu \mathrm{mol}$ and $300 \mu \mathrm{l}$ enzyme extract were used. After stirring the mixture, the glass test tubes were placed at a distance of $35 \mathrm{~cm}$ from each other under a 15-watt fluorescent lamp for 10 minutes. The reaction was stopped by turning off the lamp and the absorption of the reaction mixture was read at $560 \mathrm{~nm}$ with a spectrophotometer. Also, a test tube containing the reaction mixture with the exception of the enzyme extract was used as control. A unit of the superoxide dismutase activity was considered as an enzyme level, resulting in a $50 \%$ reduction of nitro blue tetrazolium light recovery (Giannopolitis, 1977).The SOD activity was expressed as $\mathrm{U} \mathrm{g}^{-1}$ protein.

\subsubsection{Catalase activity (CAT)}

The reaction complex consists of $1.5 \mathrm{ml}$ potassium phosphate buffer at concentration of $100 \mathrm{mmol}(\mathrm{pH}=$ 7), $0.5 \mathrm{ml}$ of hydrogen peroxide $7.5 \mathrm{mmol}$ and $50 \mu \mathrm{l}$ of enzyme solution. The volume of samples was adjusted to $3 \mathrm{ml}$ by adding distilled water. The reaction begins with the addition of hydrogen peroxide and a decrease was submitted in absorbance of the samples at $240 \mathrm{~nm}$ in one minute. The change in absorbance obtained in one minute, was subjected to a molar offset of this reaction, which is $36.6 \mathrm{mM} \mathrm{cm}^{-1}$, and the enzyme activity was determined by the calculation of the amount of hydrogen peroxide degraded by the enzyme (Aebi, 1984). The CAT activity was expressed as $\mathrm{U} \mathrm{g}^{-1}$ protein.

\subsubsection{Peroxidase activity (POD)}

For this purpose, $3 \mathrm{ml}$ of sodium phosphate buffer at concentration of 0.1 molar and $50 \mu$ of pure guaiacol liquid $\left(\mathrm{C}_{7} \mathrm{H}_{8} \mathrm{O}_{2}\right)$ and then $50 \mu$ of hydrogen peroxide $\left(\mathrm{H}_{2} \mathrm{O}_{2}\right)$ $3 \%$ were added to the enzyme extract and immediately the changes in the light absorption at $436 \mathrm{~nm}$ were recorded using a spectrophotometer at intervals of $15 \mathrm{sec}-$ onds for 3 minutes. After adding oxygenated water and guaiacol, the solution was reddish-brown. To calculate the activity of the peroxidase enzyme, the last absorption number was reduced from the first absorbed number and divided into 3 (Mac-Adam et al., 1992). The POD activity was expressed as $\mathrm{U} \mathrm{g}^{-1}$ protein.

\subsubsection{Ascorbate peroxidase (APX)}

The amount of ascorbate peroxidase enzyme activity was measured by Ranieri et al. (2003) method. As a result of the reaction between ascorbate peroxidase and ascorbic acid and $\mathrm{H}_{2} \mathrm{O}_{2}$, dehydroascorbate is produced and recorded at a wavelength of $290 \mathrm{~nm}$. The reaction medium contained $600 \mu \mathrm{l}$ of $0.1 \mathrm{mmol}$ EDTA, $1500 \mu \mathrm{l}$ phosphate buffer $50 \mathrm{mmol}(\mathrm{pH}=7), 400 \mu \mathrm{l}$ ascorbic acid $0.5 \mathrm{mmol}$, $400 \mu \mathrm{H}_{2} \mathrm{O}_{2} 30 \%$ and $100 \mu \mathrm{l}$ of enzyme extract. Enzyme activity measurements were recorded within 4 minutes. Over time, the amount of absorption increased and the APX activity was expressed as $\mathrm{Ug}^{-1}$ protein.

\subsection{STATISTICAL ANALYSIS}

This experiment was a factorial based on completely randomized design with 18 treatments and each treatment including 3 replications. Statistical analysis of the data and comparison of the meanings were performed using SAS 9.1 and MSTAT-C and comparing the meanings was performed with Duncan's multiple range test.

\section{RESULTS AND DISCUSSIONS}

According to Table 1, the main effect of time (storage period) and the main effect of treatments on the lesion diameter and activity of all antioxidant enzymes of fruit was significant at $1 \%$ level. Also, the interaction effects of treatment in time on fruit lesion diameter, as well as the activity of catalase and peroxidase enzymes were significant at a probability level of $1 \%$, but did not have any significant effect on other enzymes.

\subsection{LESION DIAMETER}

The lesion diameter on the surface of "ThomsonNavel' orange was initially zero. However, it gradually increased over time, at 48 hours after inoculation, and every 24 hours, there was a significant difference with other courses, and on the fourth day (96 hours after inoculation) it reached its highest level (Table 2). Regarding the process of controlling the fungal rot of the fruit under the influence of treatments in 96 hours after inoculation, all treatments except the treatment of $10 \mu \mathrm{ll}^{-1}$ jasmonic acid prevented the growth of green mold on the surface of the 
Table 1: Analysis of variance of different treatments on the amount of lesion diameter and activity of CAT, POD, SOD and APX enzymes in orange fruit of Thomson-Navel variety within 96 hours after inoculation.

\begin{tabular}{|c|c|c|c|c|c|c|}
\hline \multirow[b]{2}{*}{ Sources of changes } & \multirow[b]{2}{*}{$\begin{array}{l}\text { Degrees of } \\
\text { freedom }\end{array}$} & \multicolumn{5}{|l|}{ Sum of squares } \\
\hline & & $\begin{array}{l}\text { Amount of lesion } \\
\text { diameter }\end{array}$ & CAT & SOD & POD & APX \\
\hline Time (storage period) & 3 & $109 / 38^{* *}$ & $21668325^{* *}$ & $4 / 13^{* *}$ & $3984 / 2^{* *}$ & $33385 / 5^{* *}$ \\
\hline treatment & 17 & $0 / 78^{* *}$ & $399316^{* *}$ & $0 / 352^{* *}$ & $58 / 46^{* *}$ & $892 / 17^{* *}$ \\
\hline Treatment $\times$ Time & 51 & $0 / 08^{* *}$ & $85421^{* *}$ & $0 / 142^{\mathrm{ns}}$ & $24 / 66^{* *}$ & $40 / 97^{\text {ns }}$ \\
\hline Test error & 144 & $0 / 015$ & 30038 & $0 / 129$ & $9 / 6$ & $37 / 65$ \\
\hline Coefficient of variation & & $4 / 69$ & $3 / 77$ & $15 / 43$ & $7 / 54$ & $8 / 48$ \\
\hline
\end{tabular}

** show significant effect at 1 statistically level; ns: statistically non-significant

Table 2: Interaction effects of the treatment in time on the mean lesion diameter $(\mathrm{cm})$ on the surface of 'Thomson-Navel' orange fruit during 96 hours after inoculation

\begin{tabular}{|c|c|c|c|c|c|c|c|c|c|c|}
\hline \multirow{3}{*}{$\frac{\text { Treatments }}{\text { Control (+) }}$} & \multicolumn{10}{|c|}{ Time (Hours) } \\
\hline & \multicolumn{3}{|c|}{0} & \multicolumn{2}{|l|}{24} & \multicolumn{2}{|c|}{48} & 72 & \multicolumn{2}{|c|}{96} \\
\hline & 0 & $\mathrm{t}$ & 0 & $\mathrm{t}$ & 0 & $\mathrm{t}$ & 0 & $\mathrm{t}$ & 0 & $\mathrm{~T}$ \\
\hline Control (-) & 0 & $\mathrm{t}$ & 0 & $\mathrm{t}$ & 1.4 & $\mathrm{o}$ & 3.22 & $\mathrm{f}$ & 4.75 & A \\
\hline JA $5 \mu \mathrm{l}^{-1}$ & 0 & $\mathrm{t}$ & 0 & $\mathrm{t}$ & 1.05 & pqr & 2.65 & ijk & 3.89 & De \\
\hline JA $10 \mu \mathrm{ll}^{-1}$ & 0 & $\mathrm{t}$ & 0 & $\mathrm{t}$ & 1.13 & opq & 2.54 & $\mathrm{jkl}$ & 4.47 & $\mathrm{Ab}$ \\
\hline JA $20 \mu \mathrm{ll}^{-1}$ & 0 & $\mathrm{t}$ & 0 & $\mathrm{t}$ & 1.06 & pqr & 2.56 & $\mathrm{jkl}$ & 3.97 & Cde \\
\hline JA $40 \mu \mathrm{ll}^{-1}$ & 0 & $\mathrm{t}$ & 0 & $\mathrm{t}$ & 1.11 & opq & 2.48 & $\mathrm{klm}$ & 4.03 & $\mathrm{Cd}$ \\
\hline EP $1 \mu \mathrm{mol} \mathrm{l} l^{-1}$ & 0 & $\mathrm{t}$ & 0 & $\mathrm{t}$ & 1.36 & op & 2.9 & ghi & 3.81 & De \\
\hline $\mathrm{EP} 4 \mu \mathrm{mol} \mathrm{l}^{-1}$ & 0 & $\mathrm{t}$ & 0 & $\mathrm{t}$ & 0.39 & $\mathrm{~s}$ & 2.22 & $\mathrm{mn}$ & 3.7 & $\mathrm{E}$ \\
\hline $\mathrm{EP} 7 \mu \mathrm{mol} \mathrm{l}^{-1}$ & 0 & $\mathrm{t}$ & 0 & $\mathrm{t}$ & 1.25 & opq & 3.01 & fgh & 4.24 & $\mathrm{Bc}$ \\
\hline EP $10 \mu \mathrm{mol} \mathrm{l}^{-1}$ & 0 & $\mathrm{t}$ & 0 & $\mathrm{t}$ & 1.02 & pqr & 2.68 & ijk & 3.9 & $\mathrm{De}$ \\
\hline Cin $250 \mathrm{ppm}$ & 0 & $\mathrm{t}$ & 0 & $\mathrm{t}$ & 1.3 & op & 2.91 & ghi & 3.8 & De \\
\hline Cin 500 ppm & 0 & $\mathrm{t}$ & 0 & $\mathrm{t}$ & 1.25 & opq & 3.17 & fg & 4.07 & $\mathrm{Cd}$ \\
\hline Cin $750 \mathrm{ppm}$ & 0 & $\mathrm{t}$ & 0 & $\mathrm{t}$ & 0.81 & $\mathrm{r}$ & 2.34 & $\operatorname{lmn}$ & 2.78 & $\mathrm{Hij}$ \\
\hline Cin 1000 ppm & 0 & $\mathrm{t}$ & 0 & $\mathrm{t}$ & 1.03 & pqr & 2.39 & $\mathrm{k}-\mathrm{n}$ & 2.95 & $f-i$ \\
\hline Chi $2.5 \mathrm{~g} \mathrm{l}^{-1}$ & 0 & $\mathrm{t}$ & 0 & $\mathrm{t}$ & 1.36 & op & 3.04 & fgh & 4.08 & $\mathrm{Cd}$ \\
\hline Chi $5 \mathrm{~g} \mathrm{l}^{-1}$ & 0 & $\mathrm{t}$ & 0 & $\mathrm{t}$ & 1.2 & opq & 2.22 & $\mathrm{mn}$ & 3.2 & $\mathrm{Fg}$ \\
\hline Chi $7.5 \mathrm{~g} \mathrm{l}^{-1}$ & 0 & $\mathrm{t}$ & 0 & $\mathrm{t}$ & 1.12 & opq & 2.15 & $\mathrm{n}$ & 3.03 & Fgh \\
\hline Chi $10 \mathrm{~g} \mathrm{l}^{-1}$ & 0 & $\mathrm{t}$ & 0 & $\mathrm{t}$ & 0.96 & $\mathrm{qr}$ & 2.11 & $\mathrm{n}$ & 2.9 & Ghi \\
\hline
\end{tabular}

${ }^{*}$ In each column, means with the similar letters are not significant different $(p<0.05)$ using LSD test.

fruit and also caused a significant difference to the negative control. So negative control treatment (untreated and infected with green mold) with a $4.75 \mathrm{~cm}$ diameter resulted in the highest lesion diameter on the surface of the fruit, which approximately all of the surface of fruit covered with green mold mycelium. On the other hand, positive control treatment, showed the lowest lesion diameter in 96 hours after inoculation, which had no infection, followed by, the essential oil of cinnamon at concentrations of 750 and $1000 \mathrm{ppm}$, and chitosan at concentrations of 7.5 and
$10 \mathrm{gl}^{-1}$, without significant differences, could prevent from expansion of fungal infection on the fruit surface. The results indicated that $750 \mathrm{ppm}$ cinnamon treatment reduced fungal infection by $53 \%$ compared with negative control.

\subsection{EVALUATION OF SUPEROXIDE DISMUTASE ENZYME ACTIVITY}

According to Table 3 and 4, the highest amount of 
Table 3: Mean comparison of the effect of the jasmonic acid (ja) and epibrassinolide (epiBL) on the superoxide dismutase (SOD) and ascorbate peroxidase (APX) activity in 'Thomson-Navel' orange fruit during 96 hours after inoculation

\begin{tabular}{|c|c|c|c|c|c|c|c|c|}
\hline & \multicolumn{8}{|c|}{ After 96 hours of inoculation } \\
\hline & Day 0 & Control $^{+}$ & Control $^{-}$ & $1 \mu \mathrm{mol} . \mathrm{l}^{-1}$ & $4 \mu \mathrm{mol} . \mathrm{l}^{-1}$ & $7 \mu \mathrm{mol} . \mathrm{l}^{-1}$ & $10 \mu \mathrm{mol} . \mathrm{l}^{-1}$ & \\
\hline $\begin{array}{l}\mathrm{SOD} \\
\left(\mathrm{Ug}^{-1} \text { protein }\right)\end{array}$ & 2.54 & $2.42 \pm 0.18 \mathrm{abc}$ & $2.08 \pm 0.25 c$ & $2.19 \pm 0.3 b c$ & $2.23 \pm 0.2 b c$ & $2.36 \pm 0.35 \mathrm{abc}$ & $2.42 \pm 0.22 \mathrm{abc}$ & \\
\hline \multirow{2}{*}{$\begin{array}{l}\text { APX } \\
\left.\text { ( } \mathrm{U} \mathrm{g}^{-1} \text { protein }\right) \\
\end{array}$} & 52.1 & $76.15 \pm 2.97 \mathrm{bcdef}$ & $70.15 \pm 2.97 i$ & $75.63 \pm 2.61 \mathrm{defgh}$ & $77.08 \pm 2.66 \mathrm{cdef}$ & $76.26 \pm 2.67 \mathrm{bcdef}$ & $\mathrm{f} 74.2 \pm 2.23 \mathrm{gh}$ & 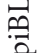 \\
\hline & Day 0 & Control $^{+}$ & Control $^{-}$ & $5 \mu \mathrm{l} . \mathrm{l}^{-1}$ & $10 \mu \mathrm{l} . \mathrm{I}^{-1}$ & $20 \mu \mathrm{l} . \mathrm{I}^{-1}$ & $40 \mu \mathrm{l} . \mathrm{I}^{-1}$ & \\
\hline $\begin{array}{l}\text { SOD } \\
\left.\text { ( } \mathrm{U} \mathrm{g}^{-1} \text { protein }\right)\end{array}$ & 2.54 & $2.42 \pm 0.18 \mathrm{abc}$ & $2.08 \pm 0.25 c$ & $2.33 \pm 0.2 \mathrm{bc}$ & $2.29 \pm 0.14 \mathrm{bc}$ & $2.37 \pm 0.25 \mathrm{abc}$ & $2.694 \pm 0.24 \mathrm{a}$ & \\
\hline $\begin{array}{l}\text { APX } \\
\left(\mathrm{U} \mathrm{g}^{-1} \text { protein }\right)\end{array}$ & 52.1 & $76.15 \pm 2.97 \mathrm{bcdef}$ & $70.15 \pm 2.97 \mathrm{i}$ & $80.07 \pm 2.76 \mathrm{a}$ & $78.79 \pm 2.59 b$ & $77.34 \pm 2.58 \mathrm{bcde}$ & $74.46 \pm 2.2 \mathrm{fgh}$ & $\underline{E}$ \\
\hline
\end{tabular}

${ }^{*}$ Means are average values of three replications with the standard error. Values followed by the same letter in the rows are not significantly different at $(p=0.05)$ according to Duncan's multiple range test.

Table 4: Mean comparison between the effect of the chitosan (chi) and cinnamon essential oil (cin) on the superoxide dismutase (SOD) and ascorbate peroxidase (APX) activity in 'Thomson-Navel' orange fruit during 96 hours after inoculation

\begin{tabular}{|c|c|c|c|c|c|c|c|c|}
\hline & \multicolumn{8}{|c|}{ After 96 hours of inoculation } \\
\hline & Day 0 & Control $^{+}$ & Control $^{-}$ & $2.5{\mathrm{~g} .1^{-1}}^{-1}$ & 5 g.l ${ }^{-1}$ & $7.5 \mathrm{~g} .1^{-1}$ & $10 \mathrm{~g} \cdot \mathrm{l}^{-1}$ & \\
\hline $\begin{array}{l}\text { SOD } \\
\left(\mathrm{Ug}^{-1} \text { protein }\right)\end{array}$ & 2.54 & $\begin{array}{l}2.42 \pm 0.18 \\
\mathrm{abc}\end{array}$ & $\begin{array}{l}2.08 \pm 0.25 \\
\text { c }\end{array}$ & $\begin{array}{l}2.11 \pm 0.22 \\
\text { C }\end{array}$ & $\begin{array}{l}2.25 \pm 0.27 \\
\text { bc }\end{array}$ & $\begin{array}{l}2.5 \pm 0.26 \\
a b\end{array}$ & $\begin{array}{l}2.44 \pm 0.28 \\
\text { abc }\end{array}$ & \\
\hline $\begin{array}{l}\mathrm{APX} \\
\left(\mathrm{U} \mathrm{g}^{-1} \text { protein }\right)\end{array}$ & 52.1 & $\begin{array}{l}76.15 \pm 2.97 \\
\text { bcdef }\end{array}$ & $\begin{array}{l}70.15 \pm 2.97 \\
\mathrm{i}\end{array}$ & $\begin{array}{l}75.99 \pm 2.6 \\
\text { cdefgh }\end{array}$ & $\begin{array}{l}74.7 \pm 2.53 \\
\text { abcd }\end{array}$ & $\begin{array}{l}76.71 \pm 2.61 \\
\text { bcdef }\end{array}$ & $\begin{array}{l}77.3 \pm 2.36 \\
\text { bcd }\end{array}$ & U \\
\hline & Day 0 & Control $^{+}$ & Control $^{-}$ & $250 \mathrm{ppm}$ & 500 ppm & $750 \mathrm{ppm}$ & $1000 \mathrm{ppm}$ & \\
\hline $\begin{array}{l}\text { SOD } \\
\left(\mathrm{U} \mathrm{g}^{-1} \text { protein }\right)\end{array}$ & 2.54 & $\begin{array}{l}2.42 \pm 0.18 \\
\mathrm{abc}\end{array}$ & $\begin{array}{l}2.08 \pm 0.25 \\
\text { c }\end{array}$ & $\begin{array}{l}2.25 \pm 0.13 \\
\text { bc }\end{array}$ & $\begin{array}{l}2.16 \pm 0.32 \\
\text { bc }\end{array}$ & $\begin{array}{l}2.34 \pm 0.14 \\
\text { bc }\end{array}$ & $\begin{array}{l}2.69 \pm 0.21 \\
\mathrm{a}\end{array}$ & \\
\hline $\begin{array}{l}\mathrm{APX} \\
\left(\mathrm{U} \mathrm{g}^{-1} \text { protein }\right)\end{array}$ & 52.1 & $\begin{array}{l}76.15 \pm 2.97 \\
\text { bcdef }\end{array}$ & $\begin{array}{l}70.15 \pm 2.97 \\
\mathrm{i}\end{array}$ & $\begin{array}{l}76.41 \pm 2.6 \\
\text { bcdef }\end{array}$ & $\begin{array}{l}76.47 \pm 2.54 \\
\text { bcdef }\end{array}$ & $\begin{array}{l}76.07 \pm 2.75 \\
\text { cdefgh }\end{array}$ & $\begin{array}{l}73.39 \pm 2.44 \\
h\end{array}$ & 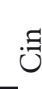 \\
\hline
\end{tabular}

${ }^{*}$ Means are average values of three replications with the standard error. Values followed by the same letter in the rows are not significantly different at $(p=0.05)$ according to Duncan's multiple range test.

SOD activity with value of 2.694 ( $\mathrm{U} \mathrm{g}^{-1}$ protein) was observed in jasmonic acid treatment at a concentration of $40 \mu \mathrm{ll}^{-1}$.The lowest activity of the enzyme was obtained by negative control treatment with the value of 2.089 (U $\mathrm{g}^{-1}$ protein) which except for $40 \mu \mathrm{l} \mathrm{l}^{-1}$ concentration of jasmonic acid, cinnamon $1000 \mathrm{ppm}$ and chitosan $7.5 \mathrm{~g} \mathrm{l}^{-1}$, had not significant difference to other treatments.

\subsection{EVALUATION OF ASCORBATE PEROXIDASE ENZYME ACTIVITY}

According to Table 3 and 4, all treatments increased enzyme activity and caused a significant difference with negative control. So, the lowest ascorbate peroxidase activity was observed in negative control treatment with a value of 70.157 ( $\mathrm{U} \mathrm{g}^{-1}$ protein). On the contrary, Apx enzyme activity was the highest in the treatment of jasmonic acid at a concentration of $5 \mu \mathrm{l}^{-1}$ with a value of 80.076 ( $\mathrm{U} \mathrm{g}^{-1}$ protein) which except for $5 \mathrm{~g} \mathrm{l}^{-1}$ chitosan, had a significant difference to other treatments.

\subsection{EVALUATION OF CATALASE ENZYME AC- TIVITY}

The activity level of the catalase enzyme, was initially 3648 ( $\mathrm{U} \mathrm{g}^{-1}$ protein) and increased over time. However, the effect of the treatments on the activity of the enzyme during the measurement period did not follow a steady pattern and at different times, it gave different responses to the concentrations in treatments (Table 5). Regarding the process of enzyme changes under the influence of treatments, all treatments, except $5 \mu \mathrm{ll}^{-1}$ jasmonic acid 
Table 5: Interaction effects of the treatment in time on changes in the catalase (CAT) activity level ( $\mathrm{Ug}^{-1}$ protein) of the 'Thomson-Navel' orange fruit in 96 hours after inoculation

\begin{tabular}{|c|c|c|c|c|c|c|c|c|}
\hline \multirow[b]{2}{*}{ Treatments } & \multicolumn{8}{|c|}{ Time (Hours) } \\
\hline & 0 & & 48 & & 72 & & 96 & \\
\hline Control (+) & 3648 & $\mathrm{y}$ & 4261 & $\mathrm{w}$ & 4425 & uv & 4575.67 & Stu \\
\hline Control (-) & 3648 & $\mathrm{y}$ & 4094 & $\mathrm{x}$ & 4190.33 & $w x$ & 4412 & $\mathrm{~V}$ \\
\hline JA $5 \mu \mathrm{l} \mathrm{l}^{-1}$ & 3648 & $\mathrm{y}$ & 4744.67 & o-r & 4622.33 & rst & 4472 & Tuv \\
\hline JA $10 \mu \mathrm{l}^{-1}$ & 3648 & $\mathrm{y}$ & 4839 & $1-q$ & 4833.67 & $1-q$ & 4830.67 & $1-q$ \\
\hline JA $20 \mu \mathrm{l}^{-1}$ & 3648 & $\mathrm{y}$ & 5077 & $e-i$ & 4957 & h-n & 5020.33 & $\mathrm{f}-\mathrm{k}$ \\
\hline JA $40 \mu \mathrm{l}^{-1}$ & 3648 & $\mathrm{y}$ & 5078.33 & $e-i$ & 4899 & j-o & 4936 & $i-n$ \\
\hline EP $1 \mu \mathrm{mol} 1^{-1}$ & 3648 & $\mathrm{y}$ & 4879.33 & $k-p$ & 4881.33 & $\mathrm{k}-\mathrm{p}$ & 5271.67 & $\mathrm{Abc}$ \\
\hline $\mathrm{EP} 4 \mu \mathrm{mol} \mathrm{l}{ }^{-1}$ & 3648 & $\mathrm{y}$ & 4994.33 & $f-m$ & 5052 & $f-j$ & 5347.67 & A \\
\hline EP $7 \mu \mathrm{mol} \mathrm{l}^{-1}$ & 3648 & $\mathrm{y}$ & 5133 & $c-g$ & 5114.33 & $c-h$ & 5159.33 & $b-f$ \\
\hline $\mathrm{EP} 10 \mu \mathrm{mol} \mathrm{l}^{-1}$ & 3648 & $\mathrm{y}$ & 5054.67 & $f-j$ & 5230.33 & a-e & 5246.33 & $a-d$ \\
\hline Cin $250 \mathrm{ppm}$ & 3648 & $\mathrm{y}$ & 4710.33 & qrs & 4963 & g-n & 5102 & $\mathrm{~d}-\mathrm{i}$ \\
\hline Cin 500 ppm & 3648 & $\mathrm{y}$ & 4825.33 & $\mathrm{~m}-\mathrm{q}$ & 5100.67 & $d-i$ & 5297 & $\mathrm{Ab}$ \\
\hline Cin $750 \mathrm{ppm}$ & 3648 & $\mathrm{y}$ & 4999.33 & $f-1$ & 4985 & $\mathrm{~g}-\mathrm{m}$ & 5307 & $\mathrm{Ab}$ \\
\hline Cin 1000 ppm & 3648 & $\mathrm{y}$ & 4723.67 & $\mathrm{p}-\mathrm{s}$ & 4978.33 & $g-n$ & 5023 & $\mathrm{f}-\mathrm{k}$ \\
\hline Chi $2.5 \mathrm{~g} \mathrm{l}^{-1}$ & 3648 & $\mathrm{y}$ & 4626.33 & rst & 4813.33 & $\mathrm{n}-\mathrm{q}$ & 4730 & $\mathrm{p}-\mathrm{s}$ \\
\hline Chi $5 \mathrm{~g} \mathrm{l}^{-1}$ & 3648 & $\mathrm{y}$ & 4268.33 & $\mathrm{w}$ & 4432.33 & uv & 4640.67 & Rs \\
\hline Chi $7.5 \mathrm{~g} \mathrm{l}^{-1}$ & 3648 & $\mathrm{y}$ & 4570 & $s-\mathrm{V}$ & 4705.67 & qrs & 4703 & Qrs \\
\hline Chi $10 \mathrm{~g} \mathrm{l}^{-1}$ & 3648 & $\mathrm{y}$ & 4458 & uv & 4475.33 & tuv & 4694.33 & Qrs \\
\hline
\end{tabular}

${ }^{*}$ Means are average values of three replications with the standard error. Values followed by the same letter in the rows are not significantly different at $(p=0.05)$ according to Duncan's multiple range test.

treatment, increased enzyme activity and showed a significant difference compared to negative control. 96 hours after inoculation, the negative control had the lowest activity of the catalase enzyme with a value of $4412\left(\mathrm{U} \mathrm{g}^{-1}\right.$ protein) and the highest activity was 5347 ( $\mathrm{U} \mathrm{g}^{-1}$ protein) associated with epibrassinolide treatment at a concentration of $4 \mu \mathrm{mol} \mathrm{l}^{-1}$.This process was observed by passing about 48 and 72 hours from inoculation. Therefore, the effect of the treatments increased with an increase in the length of the period from 48 hours to 96 hours, resulting in more enzyme changes.

\subsection{EVALUATION OF PEROXIDASE ENZYME ACTIVITY}

In general, the amount of peroxidase activity after infection with green mold was initially 28.75 ( $\mathrm{U} \mathrm{g}^{-1}$ protein) and increased over time. However, similar to the changes in the catalase enzyme activity, the effect of the treatments on the activity of the peroxidase during the measurement period did not follow a constant pattern and at different times, it gave different responses to the treatment's concentrations (Table 6). Regarding the changes in the activity of the enzyme under the influence of treatments, except for treatment of $10 \mathrm{\mu l} \mathrm{l}^{-1}$ jasmonic acid, other treatments indicated a significant difference compared to the negative control treatment. 96 hours after inoculation, the negative control had the lowest activity of the peroxidase enzyme with a value of 41.73 ( $\mathrm{U} \mathrm{g}^{-1}$ protein) and the highest activity was 60.63 ( $\mathrm{U} \mathrm{g}^{-1}$ protein) associated with epibrassinolide treatment at a concentration of $10 \mu \mathrm{mol} \mathrm{l}^{-1}$ which had a significant difference to all treatments.

\subsection{CORRELATIONS BETWEEN ANTIOXIDANT ENZYMES AND LESION DIAMETER}

According to table 7, the enzymes activity of catalase, superoxide dismutase, ascorbate peroxidase at $1 \%$ probability level and peroxidase at $5 \%$ probability level were negatively correlated with lesion diameter. Therefore, along with increase of the enzyme activity, the incidence and spread of the infection decreased (marked gray color). 
Table 6: Interaction effects of the treatment in time on changes in the catalase (CAT) activity level ( $\mathrm{Ug}^{-1}$ protein) of the 'Thomson-Navel' orange fruit in 96 hours after inoculation

\begin{tabular}{|c|c|c|c|c|c|c|c|c|}
\hline \multirow[b]{2}{*}{ Treatments } & \multicolumn{8}{|c|}{ Time (Hours) } \\
\hline & 0 & & 48 & & 72 & & 96 & \\
\hline Control (+) & 28.75 & $\mathrm{w}$ & 36.88 & uv & 42.51 & $\mathrm{k}-\mathrm{t}$ & 44.29 & h-s \\
\hline Control (-) & 28.75 & $\mathrm{w}$ & 35.88 & $\mathrm{v}$ & 41.85 & $1-\mathrm{u}$ & 41.73 & $\mathrm{~m}-\mathrm{u}$ \\
\hline JA $5 \mu \mathrm{l}^{-1}$ & 28.75 & $\mathrm{w}$ & 40.14 & $q-v$ & 43.68 & i-s & 42.78 & $\mathrm{k}-\mathrm{t}$ \\
\hline JA $10 \mu \mathrm{l}^{-1}$ & 28.75 & $\mathrm{w}$ & 41.81 & $1-u$ & 45.49 & $e-p$ & 41.74 & $\mathrm{~m}-\mathrm{u}$ \\
\hline JA $20 \mu \mathrm{l}^{-1}$ & 28.75 & $\mathrm{w}$ & 39.44 & $\mathrm{r}-\mathrm{v}$ & 45.83 & $\mathrm{e}-\mathrm{O}$ & 46.88 & $\mathrm{~d}-\mathrm{k}$ \\
\hline JA $40 \mu \mathrm{l}^{-1}$ & 28.75 & $\mathrm{w}$ & 46.25 & e-n & 49.72 & $c-f$ & 42.85 & $k-t$ \\
\hline $\mathrm{EP} 1 \mu \mathrm{mol}{ }^{-1}$ & 28.75 & $\mathrm{w}$ & 39.38 & $s-\mathrm{v}$ & 44.44 & g-r & 51.64 & $\mathrm{Bcd}$ \\
\hline $\mathrm{EP} 4 \mu \mathrm{mol} \mathrm{l}{ }^{-1}$ & 28.75 & $\mathrm{w}$ & 40.69 & $\mathrm{p}-\mathrm{v}$ & 46.22 & $e-n$ & 46.17 & $e-n$ \\
\hline EP $7 \mu \mathrm{mol} \mathrm{l}^{-1}$ & 28.75 & $\mathrm{w}$ & 46.74 & $d-m$ & 46.76 & $\mathrm{~d}-1$ & 51.32 & $\mathrm{Bcd}$ \\
\hline $\mathrm{EP} 10 \mu \mathrm{mol} \mathrm{l}^{-1}$ & 28.75 & $\mathrm{w}$ & 41.6 & $\mathrm{n}-\mathrm{u}$ & 54.51 & $\mathrm{bc}$ & 60.63 & $\mathrm{~A}$ \\
\hline Cin 250 ppm & 28.75 & $\mathrm{w}$ & 38.33 & tuv & 43.63 & i-s & 44.63 & $g-q$ \\
\hline Cin 500 ppm & 28.75 & $\mathrm{w}$ & 40.9 & $\mathrm{o}-\mathrm{u}$ & 48.17 & $d-j$ & 47.08 & $\mathrm{~d}-\mathrm{k}$ \\
\hline Cin 750 ppm & 28.75 & $\mathrm{w}$ & 45.9 & e-o & 44.93 & $f-q$ & 55.35 & $\mathrm{Bcd}$ \\
\hline Cin 1000 ppm & 28.75 & $\mathrm{w}$ & 42.29 & $k-t$ & 50.36 & b-e & 49.14 & d-h \\
\hline Chi $2.5 \mathrm{~g} \mathrm{l}^{-1}$ & 28.75 & $\mathrm{w}$ & 40.21 & $q-v$ & 45.69 & $e-p$ & 45.76 & e-o \\
\hline Chi $5 \mathrm{~g} \mathrm{l}^{-1}$ & 28.75 & $\mathrm{w}$ & 43.4 & j-s & 49.31 & $d-g$ & 45.97 & $e-n$ \\
\hline Chi $7.5 \mathrm{~g} \mathrm{l}^{-1}$ & 28.75 & $\mathrm{w}$ & 46.67 & $d-m$ & 44.31 & g-s & 48.96 & d-h \\
\hline Chi $10 \mathrm{~g} \mathrm{l}^{-1}$ & 28.75 & $\mathrm{w}$ & 43.68 & is & 48.54 & $\mathrm{~d}-\mathrm{i}$ & 45.35 & $f-p$ \\
\hline
\end{tabular}

${ }^{*}$ Means are average values of three replications with the standard error. Values followed by the same letter in the rows are not significantly different at $(p=0.05)$ according to Duncan's multiple range test.

Table 7: Correlation coefficient between enzymes and lesion diameter.

\begin{tabular}{|c|c|c|c|c|c|}
\hline & CAT & SOD & POD & APX & Lesion Diameter \\
\hline CAT & 1.000 & & & & \\
\hline SOD & $0.637^{* *}$ & 1.000 & & & \\
\hline POD & $0.894^{* *}$ & $0.739^{* *}$ & 1.000 & & \\
\hline APX & $0.601^{* *}$ & $0.68^{* *}$ & $0.65^{* *}$ & 1.000 & \\
\hline Lesion Diameter & $-0.559^{* *}$ & $-0.461^{* *}$ & $-0.397^{*}$ & $-0.57^{* *}$ & 1.000 \\
\hline
\end{tabular}

** and ${ }^{*}$ show significant effect at 1 and 5 statistically levels, respectively.

Generally, with respect to the results of this experiment, treatments result in induction of fruit resistance to green mold rot at different concentrations by increasing antioxidant enzymes activity. It was observed that using treatments such as jasmonic acid at concentrations of 5 and $40 \mu \mathrm{l} \mathrm{l}^{-1}$, epibrassinolide at concentrations of 4 and $10 \mu \mathrm{mol} \mathrm{l^{-1 }}$, chitosan at concentrations of 5 and $7.5 \mathrm{~g} \mathrm{l}^{-1}$, and cinnamon essential oil at concentrations of 750 and $1000 \mathrm{ppm}$, improved the activity of the antioxidant enzymes of the fruit. Among these, cinnamon essential oil treatments with a concentration of 750 and $1000 \mathrm{ppm}$ and chitosan at concentrations of 7.5 and $10 \mathrm{~g} \mathrm{l}^{-1}$, more effectively prevented the spread of fungal infection on the fruit surface (Table 2)

It appears that induction of fruit resistance during the post-harvest period is an applicable strategy for reducing the incidence of diseases, due to the activation of defense mechanisms within the plant itself, which has broad-spectrum antibacterial activity (Walters et al., 2005). Increasing the activity of the antioxidant enzymes is one of the strategies of plants to deal with a variety of stresses. One of these enzymes is catalase, which converts hydrogen peroxide into water, thereby preventing damage of these free radicals. Therefore, high levels of antioxidant 
enzymes play an important role in inhibiting free radicals and reducing oxidative damage (Dinget al., 2002; Wang et al., 2014).

Studies have shown that methyl jasmonate is involved in the defensive mechanisms against post-harvest diseases through a complex signaling network of fruitbased monitoring interactions, which indicates an increase in the expression of proteins associated with the disease (PR) (such as chitinase, glucanase or heat shock proteins) and the accumulation of phytoalexins in the host or other antifungal compounds (Ding et al., 2002; Wang et al., 2014). Studies of Asghari and Hasanlooe (2015) have also shown that the use of methyl-jasmonate in post-harvest time has increased the activity of catalase enzyme in strawberries, which is consistent with the results of this study. Studies of Yao and Tian (2005) on peaches showed that between concentrations of 1, 10, 100 and $500 \mu \mathrm{mol} \mathrm{l}^{-1}$ of methyl jasmonate, the best and the most economical concentration for eliminating microbial growth is $1 \mu \mathrm{mol} \mathrm{l}^{-1}$. Methyl jasmonate, also causes accumulation of plant defensive proteins against pathogens in some cases (Wang et al., 2003).

Ge et al. (2015) reported that Peach treatments with brassinolide, due to its effect on increasing resistance proteins such as superoxide dismutase and peroxidase enzymes, reduced the decay caused by the $P$. expansum Link which is consistent with the findings of this study. In jujube, EBR stimulated the activity of defense-related enzymes (CAT, SOD etc.) which consequently increases the resistance to the fungus pathogen of blue mold ( $\mathrm{Zhu}$ et al., 2010). Liu et al. (2016) found that epibrassinolidestreated grapes had better post-harvest quality and a lower incidence of Botrytis rot. Zhu et al. (2015) proposed that EBR could reduce the incidence of post-harvest disease in 'Satsuma' mandarin, possibly attributable to the accumulation of $\mathrm{H}_{2} \mathrm{O}_{2}$, stress-related metabolites, and also the induction of stress-related genes. It has been suggested that BRs may help reducing decay by inducing disease resistance in fruits and also delaying their senescence (Champa et al., 2015).

Chitosan has a double effect on host-pathogen interactions as followings: It has both a direct antifungal effect and the ability of inducing defense mechanisms in plant (Romanazzi et al., 2013). First reason for the antimicrobial activity of chitosan is the positive charge amino group. Second, it interferes with negatively charged microbial cell membranes, which resulting in leakage of proteins and other intracellular constituents of pathogens (Jayaraj et al., 2009). In addition, chitosan may enter fungal cells, which inhibit the absorption of essential nutrients, and as a result inhibit or slow down the synthesis of mRNA and protein (Zhang et al., 2011).

The result of Chien et al. (2007) indicated that, by covering the 'Murcott Tangor' citrus fruit with different concentrations of chitosan, the highest concentration of chitosan had the greatest effect on fruit quality maintenance and control of fungal growth which is consistent with results obtained from this research. Jongsri et al. (2016) found that treatment of mangoes with high molecular mass chitosans resulted in the highest activity of catalase and ascorbate peroxidase enzymes; also, treatment with high molecular mass chitosan delays the decomposition of these two antioxidant enzymes. According to findings from Zeng et al. (2010) peroxidase enzyme activity significantly increased in 'Navel' orange fruits covered by chitosan, which protects plant tissues from damages caused by high levels of activated oxygen. Therefore, chitosan coatings increase the activity of antioxidants, which its main task is to protect the fruit against oxidative stresses, including senescence and ripening, and thus increasing the storage period of fruit. Results of Badawy and Rabea (2009) demonstrate that chitosan treatment reduces fungal rot, so the accumulation of mycotoxin in apples is reduced at ambient temperature.

The production and consumption of medicinal herbs in the pharmaceutical and food industries are expanding due to the active biological compounds. In addition, extensive research has begun to show that secondary metabolites of certain medicinal plants are effective in preventing the growth of pathogenic fungi and are an appropriate alternative to chemical pesticides (Pretorius et al., 2002). Negative effects of essences on fungal spore sporulation may be caused by the effect of volatiles released by the essences on mycelium surface growth or the reception / transmission of signals that were involved in the transition from vegetative to reproductive phases in the fungus (Tzortzakis and Economakis, 2007). However, suppression of spore production by plant essence can play an important role in limiting the spread of the pathogen by reducing the release of spores in the storage space and on the fruit surface (Tzortzakis and Economakis, 2007). In this study, cinnamon essential oil showed significant antifungal activity in controlling decay caused by green mold in 'Thomson-Navel' orange. The effect of essential oil in preventing fungal growth is caused by its active ingredients. Essential oil analysis has shown that the main ingredient of cinnamon essential oil is cinnamaldehyde, of which its antifungal and antimicrobial properties have been proven (Bendahou et al., 2008; Tajkarimi et al., 2010).

Wu et al. (2017) stated that citrus treatment with the main ingredient of cinnamon essential oil (cinnamaldehyde) induced superoxide dismutase activity; also, treatment with cinnamaldehyde increased the activity of catalase and peroxidase enzymes at the end of storage compared to the control samples. It was also stated that the increase of the superoxide dismutase enzyme resulted 
in effective conversion of $\mathrm{O}_{2}$ to $\mathrm{H}_{2} \mathrm{O}_{2}$ and then increased $\mathrm{H}_{2} \mathrm{O}_{2}$ decomposition by catalase enzyme under the influence of cinnamaldehyde treatment.

Han et al. (2006) and Xu et al. (2009) reported that POD activity in control treatment of the pepper plant and fruit coated with chitosan and cinnamon essential oil increased after harvest and the amount of its activity in the treated fruit at the end of storage is increasingly more than the control treatment which shows the effect of chitosan and cinnamon essential oil on increasing POD activity during storage.

\section{CONCLUSIONS}

In conclusion, the present study confirmed that treatments of 750 and 1000 ppm of cinnamon essential oil and 7.5 and $10 \mathrm{~g} \mathrm{l}^{-1}$ of chitosan, as natural substances improved the enzyme activity compared to other treatments, and thus inhibited the growth of green mold on 'Thomson-Navel' oranges in post-harvest conditions. After completing investigation of their effects on the qualitative characteristics of the fruit and achieving favorable results, it is suggested to commercially produce and apply them at their lower concentration (because of its economic costs) as a substitute for high-consumption of chemical fungicides for the purpose of reducing postharvest waste of oranges.

\section{REFRENCES}

Abdolahi, A., Hassani, A., Ghosta, Y., Javadi, T.and Meshkatalsadat, M. (2010). Essential oils as control agents of postaharvest Alternaria and Penicillium rots on tomato fruits, Journal of Food Safety, 30, 341-352. https://doi. org/10.1111/j.1745-4565.2009.00211.x

Aebi, H. E. (1984). Catalase in vitro. Methods in Enzymology, 105, 121-126. https://doi.org/10.1016/S00766879(84)05016-3

Asghari, M., Hasanlooe, A.R. (2015). Interaction effects of salicylic acid and methyl jasmonate on total antioxidant content, catalase and peroxidase enzymes activity in 'Sabrosa' strawberry fruit during storage. ScientiaHorticulturae, 197, 490-495. https://doi.org/10.1016/j.scienta.2015.10.009

Asghari, M., Hasanlooe, A.R. (2016). Methyl jasmonate effectively enhanced some defense enzymes activity and Total Antioxidant content in harvested "Sabrosa" strawberry fruit. Food science \& nutrition, 4(3), 377-383. https://doi. org/10.1002/fsn3.300

Badawy, M.E.I., Rabea, E.I. (2009). Potential of the biopolymer chitosan with different molecular weights to control postharvest gray mold of tomato fruit. Postharvest Biology and Technology, 51(1), 110-117. https://doi.org/10.1016/j. postharvbio.2008.05.018
Bautista-Banos, S., Hernandez-Lauzardo, A.N., Velazquez-del Valle, M. G., Hernandez-Lopez, M., AitBarka, E., BosquezMolina, E. and Wilson, C. L. (2006). Chitosan as Potential Natural Compounds to Control Pre and Postharvest Diseases of Horticultural Commodities. Crop Protection, 25: 108-118. https://doi.org/10.1016/j.cropro.2005.03.010

Bendahou, M., Muselli, A., Grignon-Dubois, M., Benyoucef, M., Desjobert, J.M., Bernardini, A.F. (2008). Antimicrobial activity and chemical composition of Origanum glandulosum Desf. essential oil and extract obtained by microwave extraction: Comparison with hydro distillation. Food Chemistry, 106(1), 132-139. https://doi. org/10.1016/j.foodchem.2007.05.050

Champa, W.A.H., Gill1, MIS., Mahajan, BVC., Aror, NK., BediS. (2015). Brassinosteroids improve quality of table grapes (Vitis vinifera 'Flame Seedless'. Tropical Agricultrucal Research, 26(2):368 - 379. https://doi.org/10.4038/ tar.v26i2.8099

Chien, P.J., Sheu, F., Lin, H.R. (2007). Coating citrus ('Murcott Tangor') fruit with low molecular weight chitosan increases postharvest quality and shelf life. Food chemistry, 100(3), 1160-1164. https://doi.org/10.1016/j.foodchem.2005.10.068

Coll, Y., Coll, F., Amorós, A., Pujol, M. (2015). Brassinosteroids roles and applications: an up-date.Biologia, 70(6):726-732 doi: 10.1515/biolog-2015-0085. https://doi.org/10.1515/ biolog-2015-0085

Ding, C.K., Wang, C.Y., Gross, K.C., Kenneth, C.S., David, L. (2002). Jasmonate and salicylate induce the expression of pathogenesis-related-protein genes and increase resistance to chilling injury in tomato fruit. Planta 214, 895901. https://doi.org/10.1007/s00425-001-0698-9

Droby, S., Wisniewski, M., Macarisin, D. and Wilson, C. (2009). Twenty years of postharvest biocontrol research: is it time for a new paradigm. Postharvest Biology and Technology, 52,137e145. https://doi.org/10.1016/j.postharvbio.2008.11.009

El guilli, M., Hamza, A., Clement, C., Ibriz, M., Aitbarak, E. (2016). Effectiveness of postharvest treatment with chitosan to control citrus green mold. Agriculture, 6(2), 12 https://doi.org/10.3390/agriculture6020012

FAO/WHO (2019). http://www.fao.org/faostat.

Ge, Y.H., Li, C.Y., Tang, R.X., Sun, R.H., Li, J.R. (2015). Effects of postharvest brassinolide dipping on quality parameters and antioxidant activity in peach fruit. In III International Symposium on Postharvest Pathology, Using Science to Increase Food Availability, 1144.377-384. https://doi. org/10.17660/ActaHortic.2016.1144.56

Giannopolitis, S. (1977). Superoxide dismutase. I. Occurrence in higher plants. Plant Physiology, 59, 309-314. https://doi. org/10.1104/pp.59.2.309

González-Aguilar, G., Buta, J., Wang, C. (2003). Methyl jasmonate and modified atmosphere packaging (MAP) reduce decay and maintain postharvest quality of papaya 'Sunrise'. Postharvest Biology and Technology, 28, 361370. https://doi.org/10.1016/S0925-5214(02)00200-4

Guo, J., Fang, W., Lu, H., Zhu, R., Lu, L., Zheng, X., Yu, T. (2014). Inhibition of green mold disease in mandarins by preventive applications of methyl jasmonate and antagonis- 
tic yeast Cryptococcus laurentii. Postharvest biology and technology, 88, 72-78. https://doi.org/10.1016/j.postharvbio.2013.09.008

Han, J. H., Tao, W.Y., Hao, H.K., Zhang, B.L., Jiang, W.B., Niu, T.G., et al. (2006). Physiology and quality responses of fresh-cut broccoli florets pretreated with ethanol vapor. Journal of Food Science, 71, 385-389. https://doi. org/10.1111/j.1750-3841.2006.00042.x

Jayaraj, J., Rahman, M., Wan, A., Punja, Z.K. (2009). Enhanced resistance to foliar fungal pathogens in carrot by application of elicitors. Annals of Applied Biology, 155, 71-80. https://doi.org/10.1111/j.1744-7348.2009.00321.x

Jiménez-Reyes, M.F., Carrasco, H., Olea, A., Silva-Moreno, E. (2018). Natural compounds: A sustainable alternative for controlling phytopathogens. PeerJ Reprints, 6, e26664v1. https://doi.org/10.7287/peerj.preprints.26664v1

Jongsri, P., Wangsomboondee, T., Rojsitthisak, P., Seraypheap, K. (2016). Effect of molecular weights of chitosan coating on postharvest quality and physicochemical characteristics of mango fruit. LWT-Food Science and Technology, 73, 28-36. https://doi.org/10.1016/j.lwt.2016.05.038

Ladanyia, M., Ladaniya, M. (2010). Citrus Fruit: Biology, Technology and Evaluation. Academic Press: San Diego, CA, USA.

Liu, Q., Xi, Z., Gao, J., Meng, Y., Lin, S., Zhang, Z. (2016). Effects of exogenous 24 epibrassinolide to control grey mould and maintain postharvest quality of table grapes. International Journal of Food Science and Technology, 51(5), 1236-1243. https://doi.org/10.1111/ijfs.13066

Luan, L. Y, Zhang. Z. W, Xi, Z. M, Huo, S. S, Ma, L. N. (2013). Brassinosteroids regulate anthocyanin biosynthesis in the ripening of grape berries. South African Journal of Enology and Viticulture, 34(2):196-203. https://doi. org/10.21548/34-2-1094

Mac-Adam, J.W., Nelson, C.J., Sharp, R.E. (1992). Peroxidase activity in the leaf elongation zone of tall fescue I. Spatial distribution of ionically bound peroxidase activity in genotypes differing in length of the elongation zone. Plant Physiology, 99(3), 872-878. https://doi.org/10.1104/ pp.99.3.872

N. G. Tzortzakis, C. M. Economakis. (2007). Innovative Food Science and Emerging Technologies, 8, 253. https://doi. org/10.1016/j.ifset.2007.01.002

Peng, J., Zheng, Y., Tang, S., Rui, H., Wang, C. (2009). Enhancing disease resistance in peach fruit with methyl jasmonate. Journal of the Science of Food and Agriculture, 89(5), 802-808. https://doi.org/10.1002/jsfa.3516

Pretorius, J.C., Zietsman, P.C., Eksteen, D. (2002). Fungitoxic properties of selected South African plant species against plant pathogens of economic importance in agriculture. Annals of Applied Biology, 141(2), 117-124. https://doi. org/10.1111/j.1744-7348.2002.tb00203.x

Qin, G.Z., Tian, S.P., Xu, Y., Wan, Y.K. (2003). Enhancement of biocontrol efficacy of antagonistic yeasts by salicylic acid in sweet cherry fruit. Physiological and Molecular Plant Pathology, 62(3), 147-154. https://doi.org/10.1016/S08855765(03)00046-8

Ranieri, A., Castagna, J., Pacini, B., Baldan, A., Mensuali. Sodi, G.F. (2003). Soldatini Early production and scavenging of hydrogen peroxide in the apoplast of sunflowers plants exposed to ozone. Journal of Experimental Botany, 54, 2529-2540. https://doi.org/10.1093/jxb/erg270

Reddy, M.V.B., Angers, P., Gosselin, A., Arul, J. (1997). Characterization and use of essential oil from Thymus vulgaris against Botrytis cinerea and Rhizopus stolonifer in strawberry fruits. Phytochemistry, 47, 1515-1520. https://doi. org/10.1016/S0031-9422(97)00795-4

Romanazzi, G.; Murolo, S.; Feliziani, E. (2013). Effects of an innovative strategy to contain grapevine Bois noir: Field treatment with resistance inducers. Phytopathology, 103, 785-791. https://doi.org/10.1094/PHYTO-01-13-0031-R

Shan, B., Cai, Y.Z., Brooks, J.D., Corke, H. (2007). The in vitro antibacterial activity of dietary spice and medicinal herb extracts. International Journal of food microbiology, 117(1), 112-119. https://doi.org/10.1016/j.ijfoodmicro.2007.03.003

Sharma, R.R., Singh, D., Singh, R. (2009). Biological control of postharvest diseases of fruits and vegetables by microbial antagonists: A review. Biological control, 50, 205-221. https://doi.org/10.1016/j.biocontrol.2009.05.001

T, M., Ibrahim, S., Cliver, D. (2010).Antimicrobial herb and spice compounds in food. Food Control, 21(9), 1199-1218. https://doi.org/10.1016/j.foodcont.2010.02.003

Walters, D., Wash, D., Newton, A., Lyon, G. (2005). Induced resistance for plant disease control: Maximizing the efficacy of resistance elicitors. Phytopathology, 95, 1368-1373. https://doi.org/10.1094/PHYTO-95-1368

Wang Q, Lai TF, Qin GZ, Tian SP. (2009). Response of jujube fruits to exogenous oxalic acid treatment based on proteomic analysis. Plant Cell Physiol, 50:230-242. https://doi. org/10.1093/pcp/pcn191

Wang, C.Y., Fung, R., Ding, C. (2003). Reducing chilling injury and enhancing transcript levels of heat Shock proteins, pr-proteins and alternative oxidase by methyl jasmonate and methyl salcylate in tomatoes and peppers. Meeting Abstract, 38, 860.

Wang, K.T., Jin, P., Han, L., Shang, H.T., Tang, S.S., Rui, H.J., et al. (2014). Methyl jasmonate induces resistance against Penicillium citrinum in Chinese bayberry by priming of defense responses. Postharvest Biology and Technology, 98, 90-97. https://doi.org/10.1016/j.postharvbio.2014.07.009

Wasternack, C., Hause, B. (2013). Jasmonates-Biosynthesis and Role in Stress Responses and Developmental Processes. Annals of Botany, 111, 1021-1058. https://doi. org/10.1093/aob/mct067

Win, N.K.K., Jitareerat, P., Kanlayanarat, S., Sangchote, S. (2007). Effects of cinnamon extract, chitosan coating, hot water treatment and their combinations on crown rot disease and quality of banana fruit. Postharvest biology and technology, 45(3), 333-340. https://doi.org/10.1016/j. postharvbio.2007.01.020

Wu, Y., Duan, X., Jing, G., Ouyang, Q., Tao, N. (2017). Cinnamaldehyde inhibits the mycelial growth of Geotrichum citri-aurantii and induces defense responses against sour rot in citrus fruit. Postharvest Biology and Technology, 129, 23-28. https://doi.org/10.1016/j.postharvbio.2017.03.004

Xu, W.T., Peng, X.L., Luo, Y.B., Wang, J., Guo, X., Huang, 
K.L. (2009). Physiological and biochemical responses of grape fruit seed extract dip on 'Redglobe' grape. LWTFood Science and Technology, 42, 471-476. https://doi. org/10.1016/j.lwt.2008.09.002

Yao, H.J., Tian, S.P. (2005). Effects of a biocontrol agent and methyl jasmonate on postharvest diseases of peach fruit and the possible mechanisms involved. Journal of Applied Microbiology, 98(4), 941-950. https://doi.org/10.1111/ j.1365-2672.2004.02531.x

Zeng, K., Deng, Y., Ming, J., Deng, L. (2010). Induction of disease resistance and ROS metabolism in navel oranges by chitosan. Scientia Horticulturae, 126, 223-228. https://doi. org/10.1016/j.scienta.2010.07.017

Zhang, H., Li, R. and Liu, W. (2011). Effects of Chitin and
Its Derivative Chitosan on Postharvest Decay of Fruits: A Review. International Journal of Molecular Sciences, 12(2), 917-934. https://doi.org/10.3390/ijms12020917

Zhu, F., Yun, Z., Ma, Q. (2015). Effects of exogenous 24-epibrassinolide treatment on postharvest quality and resistance of Satsuma mandarin (Citrus unshiu). Postharvest Biology and Technology, 100, 8-15. https://doi. org/10.1016/j.postharvbio.2014.09.014

Zhu, Z., Zhang. Z.Q., Qin, G.Z., Tian, S.P. (2010). Effects of brassinosteroids on postharvest disease and senescence of jujube fruit in storage. Postharvest Biology and Technology, 56, 50-55. https://doi.org/10.1016/j.postharvbio.2009.11.014 